\title{
Portraits of Painters in Islamic Painting "In light of Examples from Safawid era"
}

\author{
Reham Said el-Sayed Ismail \\ Lecturer in Islamic Department, Faculty of Archaeology, Cairo University \\ trenasaid@cu.edu.eg
}

\begin{abstract}
From the Safawid era (907-1145 H./1502 -1732 A.D.) and with the rise of painter's status in society, a major transition in mode of Persian painting had appeared. It was the technical orientation to display portraits of princes, nobles and artists. The historical origins of this technique stemmed from the European Renaissance. The purpose of this paper is to study the technique of portraits that display painters in the Safavid painting and the purpose of making them. The findings of this study show that there were two artistic directions towards an individualization of personalities: The first was Bihzad's attempt, second was the representation of beautiful young men in courtly costumes, both were presented in the late Safavid painting.
\end{abstract}

Keywords: Portraits, Painters, Safawid, Tahmasp, Bihzad, Reza Abbsi, Sam Mirza, Mohammedi, Mu'in Mswer, Self-portraits, Mani.

\section{Introduction:}

Through Islamic painting, scholars can find few portraits of painters since $10^{\text {th }}$ century (H.) $-16^{\text {th }}$ century (A.D.) in Islamic schools of painting $s$ in Iran, Turkey and India. Our subject considers a complementary study for the previous researches about the Safawid painters.

This essay examines the out shape of the Safawid painter, who displayed him? His attitude, the motives for making portraits of painters in Safawid era and the objects in these plates.

\section{Previous studies:}

Grabar (Oleg) 2002, Masterpieces of Islamic Art, Prestel.

Husain (Mahmud Ibrahim) 1989, Encyclopedia of Muslims Artists, Maw-swat al-Fananin al-Muslmen, Cairo. (In Arabic)

Khalifa (Rabbi Hammed) 2007, Islamic painting Schools in Iran, Turkey and India (9-15) to (12-19) centuries, Cairo. (In Arabic)

Rexburg (David J.) 1996, "our works point to us" Album Making, Collecting, and Art (1427-1565) Under The Timurids And Safawids, a Dissertation in History of Art, Presented to the Faculties of the University of Pennsylvania in Partial.

\section{Definition of portrait:}

The portrait is an image to describe someone. The artist uses his tools and his skills for showing the characteristics of the external shape of man ,the moral features can be shown 
too; it is based on the ability of the artist.(Mehrez,1946, Portraitis in Islamic painting, 85) (Grabar, 2002, 130) (Khalifa, 2007, 3)

\section{Reasons for making portrait in Safawid era:}

First School: There had been a passion during $10^{\text {th }}(\mathrm{H})$ century $-16^{\text {th }}(\mathrm{A} . \mathrm{D})$ century for making portraits to Sultans, courtiers and artists, which bound within a picture album "muraqqa". (Grabar, 2002, 182)

Realism in Safawid painting was inherited from Bihzad's school; even one can see real characters in plates that illustrated manuscripts in the first Safawid School. (Okasha, 1983, 222)

In the second part of $10^{\text {th }}$ (H.)-16 ${ }^{\text {th }}$ (A.D.)century, after changes that had happened in royal patronage towards painting, in addition to moving to Qazvin in 961(H.)-1555(A.D) (Robinson, 1976,). Also, Shah Tahmasp issued the edict of sincere repentance in 962(A.H)-1556(A.D); he gave permission to some painters in the royal library to practice painting for other clients. (Okasha, 1983, 265)

The artists were spreading out from royal studio, they opened their own studios for rich people and general consumption especially in Shiraz. (Grube, 1962, 85)

Second School: Art in this period was practiced away from the royal patronage, so it became less royal than in the past, at the same time there were new examples, which reflected a spirit of innovation as the portraits of public in natural background took the place of traditional subjects. (Okasha, 1983, 265, 266)

\section{Portraits of painters in Persian painting before Safawid era:}

Few portraits of painters before this era in Persia can be found, for example, there is a unique plate presents "Mani" painting a dead dog in the silver lake (pl.1), from a copy of "Khamsh" manuscript, copied in Yazd (849-1445). (Barry,2004, p.265)

However, we found portraits for sultans, princes, nobles and patrons; there were many examples in Timurid painting especially in Herat.

\section{Portraits of painters in Persian painting in Safawid era:}

It is noticeable that during the Safawid era that the status of artists became higher, especially painters who were shah's friends. (Blochet, 1929, 100) (Hassan, 18). Also, a true individualization and a fine psychological rendering can be noticed in the portraits of Safawid painters. (Barry, 2004, 182)

\section{The aim of making a portrait of some painters:}

There are different opinions regards explaining the production of portraits of painters, but all of them referred to Mani as a master of painting; some of them referred to Mani as a 
Persian painter and the Safawid dynasty was the first national state since Sassanid dominated Iran, on the other hand, Islamic painter had been inspired by God; Bihzad vanquished the artistic Manichaean idolatry. (Barry, 2004, 268)

\section{$\underline{\text { Description Portraits }}$}

\section{Mani painted a dead dog in the silver lake (pl.1)}

Mani sits in front of a magic Chinese pond that has a circle shape and has a dead dog in the center. He wears a gown that has a triangle open in front of the neck and a belt around the waste, a white turban around a cap. His face is rectangular and fat, his eyes are narrow; their pupils are in the direction of flowers. The mustache and the beard are only around the chin. Mani sits on his knees, uses a brush to paint flowers on the edge of the magical Chinese pond, next to him is the rest of his tools; two rulers and a horn. The sight is in the center of the plate, in the foreground; there are tools of the painter and grass, and there are several levels of the ground with flowering trees in the background. Persian inscription is divided into 4 columns as usual in the space under and above the plate (shape: a).

\section{Shah Tahmasp as a supervisor of his Shahname (pl.2)}

In the beginning of a huge group of plates, there is the starter plate of Firdausi with three poets from Ghazna; in the right up corner behind hills we can see "Shah Tahmasp" (930-984 H. / 1524-1576 A.D) (Welch, 1985, 72) as a small-scale figure. He is wearing simple costume similar to farmers attire, which consists of a blue jacket, short pants and a blue turban around little red cap. He was holding an axe with two hands as if he was about doing something.

We consider this little figure as a portrait for Tahmasp, presented as an artist in a way that reflects his passion for painting. It shows the Shah as an artist with simple clothes and he was ready to help and express his opinion in his Shahname's plates. He has a white skin, a slightly thick face, light beard and he seems quite young. The painter was Aqa Mirk, he was not only a friend of the Shah, but also he gave him lessons in painting. (Blochet, 1929, 100)

\section{- Comparison between portraits of "Prince Sam Mirza-Shah Tahmasp"}

The previous studies considered the character of Sam Mirza- the younger brother of the Shah- in "Eid Celebration" (pl.3) as a portrait of the patron of the book of Diwan Hafiz (Gray, 19.130) (more details about Sultan Muhammad: Canby,1990,58).

Therefore; we shall consider a figure of Shah Tahmasp in "Firdausi with Ghazna poets" (pl.2) as a portrait of supervisor of all plates of Tahmasp`s Shahnama. 
JOURNAL OF THE FACULTY OF ARCHAEOLOGY -VOLUME 25 -2022

\begin{tabular}{|l|l|l|}
\hline Comparisons & Sam Mirza & Shah Tahmasep \\
\hline Position of portrait & patron & Supervisor \\
\hline Time & The First Safavi School & The First Safavi School \\
\hline Presence & $\begin{array}{l}\text { Folio 86 recto, the book } \\
\text { of Diwan Hafiz }\end{array}$ & $\begin{array}{l}\text { The starter plate of } \\
\text { Tahmasp`s Shahnama. }\end{array}$ \\
\hline The number of people & $\begin{array}{l}\text { A plate contains plenty } \\
\text { of people around the } \\
\text { prince. }\end{array}$ & $\begin{array}{l}\text { A plate contains a few } \\
\text { people. }\end{array}$ \\
\hline Costumes & $\begin{array}{l}\text { Formal costume, it is } \\
\text { worthy to be the younger } \\
\text { brother of The Shah. }\end{array}$ & $\begin{array}{l}\text { Farmer costume, It is } \\
\text { fitting for someone who } \\
\text { is diligent in his work. }\end{array}$ \\
\hline Features & $\begin{array}{l}\text { Circle face- white skin- } \\
\text { without beard. }\end{array}$ & $\begin{array}{l}\text { Oval thick face- white } \\
\text { skin- light beard. }\end{array}$ \\
\hline Poses & $\begin{array}{l}\text { He sits on the throne in } \\
\text { the center of the plate; } \\
\text { one of his courtiers gives } \\
\text { him a cup. }\end{array}$ & $\begin{array}{l}\text { He stands in the right up } \\
\text { corner, carries an axe } \\
\text { with both of his hands. }\end{array}$ \\
\hline The artist & $\begin{array}{l}\text { Sultan Muhammed, he } \\
\text { left his signature on the } \\
\text { throne. }\end{array}$ & $\begin{array}{l}\text { Aqa Mirak, he did not } \\
\text { left his signature. }\end{array}$ \\
\hline
\end{tabular}

From the previous comparison, we can explain the true position of the Shah as a supervisor of the drawings in his Shahnama; especially he had received many lessons in painting from Bihzadian masters. There was a unique album "muraqqa" which contains some plates by Tahmasp, kept in Topkabi Saray museum, and there were some other illustrated manuscripts, for example; "al kora wa al gawkan" to Arefi - copied in (931 H.1524 A.D.). (Khalifa, 2007, 51)

\section{Kamal el-Din Bihzad (pl.4)}

Bihzad was appointed head of a new court school at Tabriz in (928 H.-1522 A.D.). The portrait was part of a large folio (pl.3i), contained four portraits for courtiers, the top right of them was Bihzad (pl.3ii). 
This plate presents "Kamal al Din Bihzad" during the time of his service in Safawid's court; this portrait was included in a collection of painting "Murraqa" known as The Album of the Emir Gayb Beg (931 H.-1525 A.D.).

A tall man presents black book and carries a portfolio (shape:h), he has a little curve in upper back and square shoulders. Although the Safawid turban with red stick was painted here; the belt around waist was painted under stomach, the background is brown, and it has an inscription in the top "صورت أستاذ بهز اد". (Rexburg, 2005, pl.108)

\section{Self-portrait of Mir Sayed Ali (pl.4)}

Self-portrait was one of the new phenomena in Safawid painting, the artist stood up in the front of a mirror and drew himself, and it was one of the European arts effects in the second part of $10^{\text {th }}-16^{\text {th }}$ century. Mir Sayed Ali was one of masters of Safawid painting. (Details about Mir Sayyid Ali: Welch, 1990, 85)

He sits squatting and carries an open book that has Persian inscription.

"غلام حضرت شاه سيد علي سيد محمد" (Grabar, 2002, 132) We can notice the artistic style of the first Safawid School, the taller body, oval face, tiny features and of course; the Safawid turban. The portrait was drawn without any colors; the painter used only pen and brush to draw folds of dresses. He wears a tight cloak and caftan with short sleeves. He is browsing a "safina" which is an album or book with long narrow white sheets of paper joined at the short edge. (Shape: f) (Canby, 2000, 78)

\section{Portrait of a painter looks into an album (pl.6)}

This plate was kept in Fine Art Museum (N.14.573), the painter sits on his knees and carries an open album, and he wears a loose gray robe, a white turban around red cap, his features are normal. The most important thing here is the flowery background, which consists of a florid branch with big flowers. It was drawn by a heavy black pen on uncolored background (shape: g). https://www.pinterest.com

\section{Self-Portrait of Mohammedi (pl.7)}

Mohammedi considered it as a renewal method. There are many opinions regards the origins of Mohammedi, one of them is that he was son of Sultan Muhammed; another opinion said he was a Chinese artist. His physical shape clearly shows that Mohammedi had origin from eastern Asia; dark skin, tall body, small features and pear face, and professional in painting are shown that his origins from the north of China. (Khalifa, 2007, p.128)

He is a tall man carries a sheet with floral decoration in his right and a dagger in his left, he wears a closed brown cloak, there is a white belt around his waist under stomach, the hem of cloak was raised and hidden, the liner of cloak is light blue, under the cloak we can notice the white gown. 
Turkman turban covered the head, there is a black cab in the middle of white turban, and he has a dark skin, it is clear in the color of his leg, but the face and hands have a light brown color, maybe the artist tried to be more handsome.

The background is blue, and at the bottom, there are inscriptions and the signature of the painter "عمل محمدي صورت محمدي". (Adamova, 2012, p.27, pl.4).

The face has expressive features; it has a gesture with drawing the face down and the eyes looking up towards the picture in the hand, the face is pear shaped with short beard and bow mustache, the nose is small, eyes are narrow, and eyebrows are straight. Mohammedi rendered himself as an individual, precise and passionate person. (shape: i).

\section{Portrait of Safawid painter (pl.8)}

This portrait was attributed to Reza- Abbasi, who shifted Persian painting character from royal to popular. Real persons were drawn in his plates (Abed el-Wahab, 1958, 28-29).

This plate was described as a portrait of a writer (Abed el-Wahab, 1958, 30). However, the paper that was held under the right hand contains drawings without any inscriptions. The painter squats in the three quarter pose, draws on a paper with a long brush.

The squatting painter sits in the three-quarters position holding with his left hand a paper and with his right a long brush. He meditates while drawing (Ismail, 2009, 220).

He wears a brown robe, opened in front of the stomach, a green shawl around the waist and a folder. The head cover is a turban that consists of a blue shawl around a big cap (Shape: d). The foreground contains flowers, leaves and drawing tools. There are a white color cup and a folder. In the background, there is a flaming halo with a radiant design; its lines are uneven and curved around the top third of painter's body. (Ismail, 2009, 220).

\section{Portraits of Reza-i Abbasy}

Mui-n Msawer drew two plates for his master after his death in (1045 H. -1635 A. D.) (Diba, 1999, 108), they are very famous in Safawid painting, many scholars studied them (details: Farhad, 1990, 120).

However, there is a question: what was the motivation for drawing a portrait of Reza Abbasi after his death? Maybe it means that: "I am his successor now; my work reflects the same style and techniques, I am reviving the classic means of my master". (Details about Reza Abbasi: Canby, 1990, 71).

The first Portrait (pl.9.) shows Reza sitting on the ground, his right leg is upright while the left is squatting (shape: b). He puts a tablet with a new plate on his upper knee, he completes the plate which illustrates a man in European clothes; he uses the pen with his right hand while he carries a little white cup with his other hand, this cup contains a color. Reza wears a red caftan, a wide shawl around the waist, and there is a dagger in his 
left side. There is a white dress under the red caftan, and a big blue shawl covers the head in Turkman turban design. Behind Reza ; there is a blue cloak, Mu-in wants to show that the cloak fell during making the plate.

Facial features are very expressive: the head is curved, the brown eyes are concentrated on the plate, and there is a circle eyeglass on the tall nose.

Colors cubs, brushes, portfolios, short table and different drawing tools are on the ground. The background is simple without any decoration except the Persian inscription, which contains the artist's signature "Mu-in Msawer work" "عمل معين مصور".

The second Portrait (pl.10.) shows Reza in the same pose and details in the previous plate, except the colors of dresses, whereas the turban is white, the caftan is blue, the cloak is white and the plate under his hand is still a draft without any colors. As for the background, it has floral decoration and some clouds in the sky. In the left side, there is a Persian inscription, which contains the year of drawing and signature of the artist at the end.

Mui-n Msawer made very successful portraits for his master through drawing his distinctive movements, for example; the little finger of the right hand is not bent during draw. This movement appears in the both of plates (shape: c).

In my opinion, Mui-n Msawer was able to Summarize his master's technical directions in both plates. In the first plate, Reza painted a man in European costume, and in the second one; he painted a dervish. Maybe it was the reason for drawing both of them; especially they were made after Reza's death.

\section{Portrait of Safawid painter (pl.11)}

This portrait that dates back to the end of second Safawid painting school, which presents a sitting painter on a mat next to a big tree under its shades, he is leaning on his right knee for painting with two papers and a pen.

Head is in profile pose, the face has a short beard, big mouth, long nose and focused eyes, while hair is covered with a cap.

Hands: there was a common style in painting the right hand, which is used with a straight pinky finger.

The artist of this plate tried to draw feet as a professional through drawing small fingers except the middle. (shape.e)

Dress is a wide robe, it has many folds of dress around joints, there is a sash around the waist, its tip is dropped down under legs, and it is a part of a uniform. 
The tools of painting are two papers and a pen, which are carried by painter, papers resting on his thighs, and there is a design that is executed, also, some tiny tools on the ground.

Background is executed in old style that depends on wide foreground, which contains the main subject; however, in the top one can see the rocky hills, horizon and a tree branch. Colors are poor and confined to brown color grades, besides usage of black lines to determine items only. Although poor colors were used, both depth and third dimension are very clear.

\section{Self-portrait signed by Muhammad Qasim (pl.12)}

Qasim is standing in three quarter pose for the body and the head, wears a Turkman style turban with a tall feather, a blue coat with a golden floral decoration, a golden Jama with a blue floral decoration, light blue pants and a black shoes with high heels (shape.j).

The style of clothing is in line with the fashion that was common in Persia in the $11^{\text {th }} \mathrm{H}$.$17^{\text {th }}$ A.D. century, the Indian effects displayed in golden wide Jama, which was very common in India at that time.

The character of the painter here was displayed as a presenter of a big rectangular paper, which was carried by his hands, contained five lines of Persian inscriptions; the last line had the name of the painter Muhammed Qasim.

Translation:

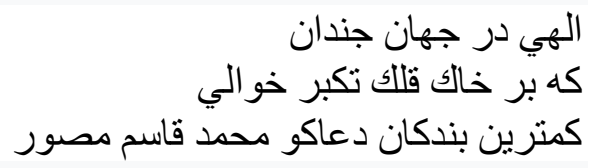

My God to remember in the world above the astronomy that the least worshiper is the good-intentioned Mohammed Qasim Musawer (translate Dr. Ahmed Sami, Lecturer, the faculty of Arts, Eastern Languages, Ain Shams University) إلهي، لنظل تذكر في العالم الغيبي أن أقل العباد هو الحسن النية محمد قاسم مصور.

Background was divided into three stages, first was a small gray rock in the right corner, second was flowering plant packs and the third was the Chinese clouds in the sky.

It is worth mentioning that there are many examples for other Safawid painters like Portrait of Fani (or Mani), (1019 H.-1610 A.D.), British Museum, OA 1948 12-11 011. Moreover a portrait of Shafi' "Abbasi, detail from the "Rida-yi Abbasi Album" second part of 11 century H.- second Quarter of $17^{\text {th }}$ century A.D., Freer Gallery of Art, 53.17. (Canby, 2000, pl.4-5) 


\section{Results:}

1- We can divide "portraits of Safawid painters" for two sections:

First was excuted by others like Shah Tahmasp, Bihzad and Reza Abbasi portraits. Second was self-portraits like Mohammedi, Mir Sayed Ali and Mohamed Qasim portraits.

2- Making portrait of painters had existed in Persian painting before the existence of European influences in Persia during the Safawid era, which appeared in the second part of $10^{\text {th }}$ H.- the second part of $16^{\text {th }}$ century A.D. . Moreover; making portraits for painters had existed in Persian painting before the Safawid era, for example; Mani`s portrait.

3- Mui-n Musawer was able summarize his master technical directions in two portraits, perhaps it was the reason for drawing both of them; especially they were made after Reza's death.

4- There were three common poses for drawing artists: first was during the work (shapes $\mathrm{a}, \mathrm{b}, \mathrm{c}, \mathrm{d}, \mathrm{e}$ ); second was while browsing an album (shapes $\mathrm{f}, \mathrm{g}$ ); third was while presenting something. (shapes $\mathrm{i}, \mathrm{h}, \mathrm{j}$ ).

5- There were two artistic directions towards an individualization of personalities:

First was Bihzad's attempt, which was based on drawing the real features of the character: like plates of Tahmasp, Sam Mirza and Bihzad, a painter looks into an album, Mohammedi, Reza Abbasi and two plates of Safawid painters.

Second was representation of beautiful young men in courtly costumes like Mir Sayed Ali and Muhammed Qasim.

Although the first artistic style was older than the second, both were used in the late Safavid painting. 


\section{References:}

1-Adamova Adel T. 2000, On the Attribution of Persian Paintings and Drawings of the Time of Shah Abbas I, Hillenbrand Robert (editor),Persian Painting, The Center of Middle Eastern Studies, University of Cambridge in association with I.B.Tauris Publishers.

2-Barry Michael 2004, Figurative Art in Medieval Islam and the Riddle of Bihzad of Herat (1465-1535), Flammarion.

3-Canby Sheila R., 2000, The Pen or the brush, Hillenbrabd(editor), Persian Painting, The Center of Middle Eastern Studies, University of Cambridge in association with I.B.Tauris Publishers.

4-Diba S. Layla \& Ekhitar Maryam (Editors) 1999, Royal Persian Paintings, Brooklyn Museum of Art in association with I.B. Tauris Publishers.

5- Farhad Massumeh 1999, The Art of Mu'in Musavvir, Canby Sheila R.(editor), Persian Masters, Marg Publication.

6-Grabar Oleg 2002, Masterpieces of Islamic Art, Prestel.

7-Grube Ernst J. 1962, Muslim Miniature Paintings from the XIII to XIX century, Venezia.

8-Hassan Zakie Mohamed, Painting and the masters of painters in Islam, Taswir wa Allam elMusawirin fi el-Islam, Cairo. (In Arabic)

9- Ismail Reham Said el-Sayed (2009), “The Nimbus in Islamic painting”, al Hala fi al Tasweer al Islamy, Master thesis, unpublished, faculty of Archaeology, Cairo University. (In Arabic)

10-Khalifa Rabbi Hamid 2007, Islamic painting Schools in Iran, Turkey and India (9-15) to (1219) centuries, Cairo.

11-Mehrez Gamal Muhammed (1946), Portraits in Islamic painting, Al Rosoom Al Shakhsyia fi al Tasweer al Islamy, Journal of the Faculty of Arts, Vol. 8(1), May 1946, Foad I University. (In Arabic)

12-Robinson (editor) 1976, Islamic painting and the arts of the book, London.

13- Welch Stuart Carry 1976, Royal Persian Manuscripts, London.

14-Welch Anthony 1999, The worldly vision of Mir Sayyid Ali, Canby Sheila R.(editor), Persian Masters, Marg Publication.

15-Abed el-Wahab Mohamed Abbas 1958, Reza- Abbasi, 'the Magazine”, vol. 16, second year, Cairo.

\section{Websites:}

https://commons.wikimedia.org/w/index.php?curid=7828267(12/2/2019)

https://www.pinterest.com/search/pins/?q=portraits\%20of\%20painters\%20in\%20safawid\%20pai nting\&rs=typed\&term_meta[]=portraits $\% 20$ of $\% 20$ painters $\% 20$ in $\% 20$ safawid $\% 20$ painting $\% 7 \mathrm{Ct}$

yped(6/3/2021)

https://www.si.edu/museums/freer-gallery

http://www.bl.uk 
Shapes

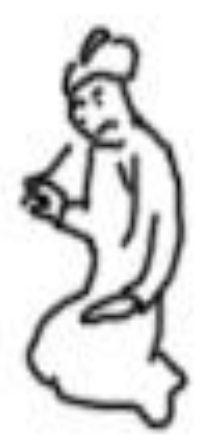

(a)

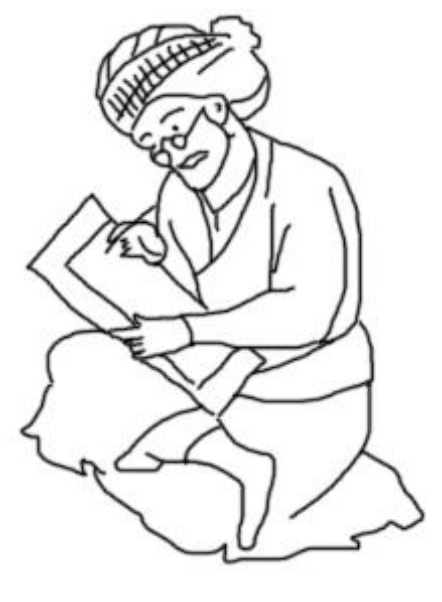

(b)

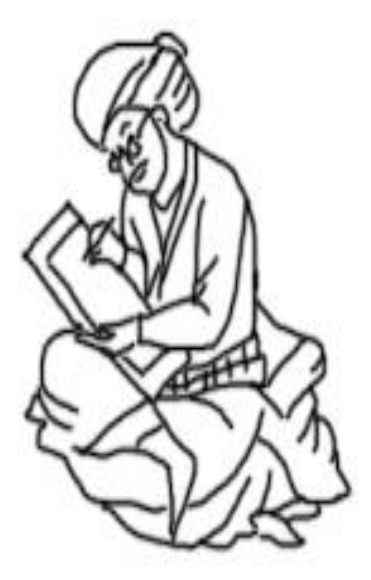

(c)

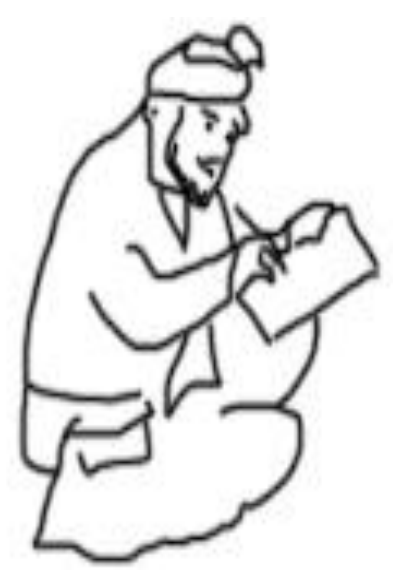

(d)

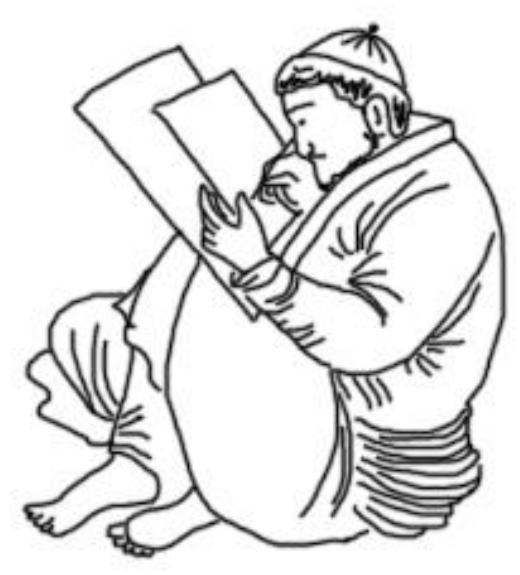

(e)

Portraits while working

Researcher's work 


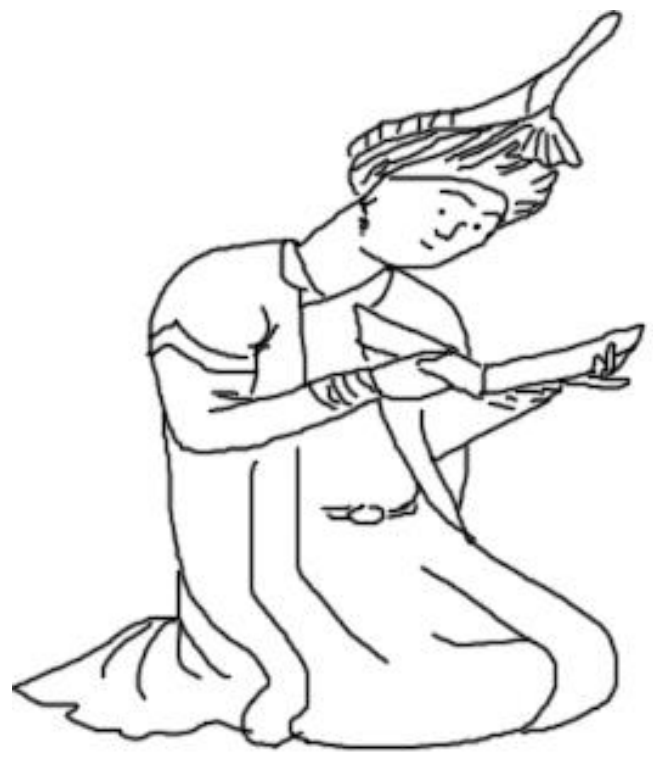

(f)

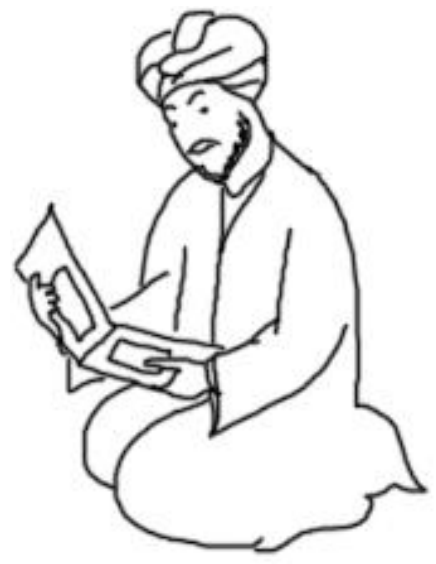

(g)

portraits while browsing

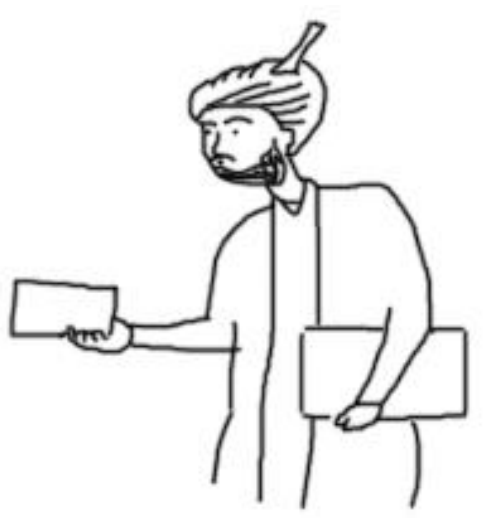

(h)

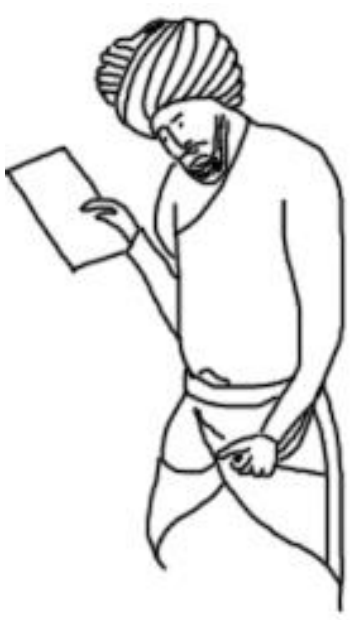

(i)

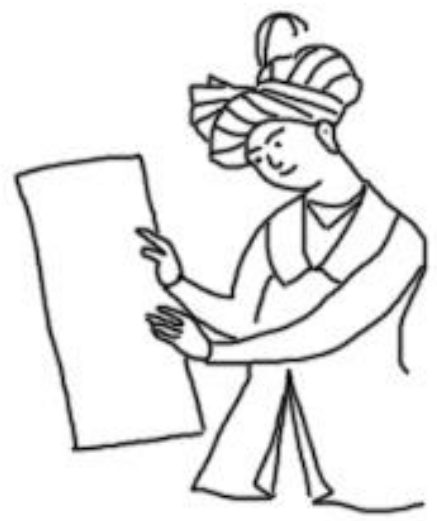

(j)

portraits while presenting

Researcher's work 


\section{$\underline{\text { Plates }}$}

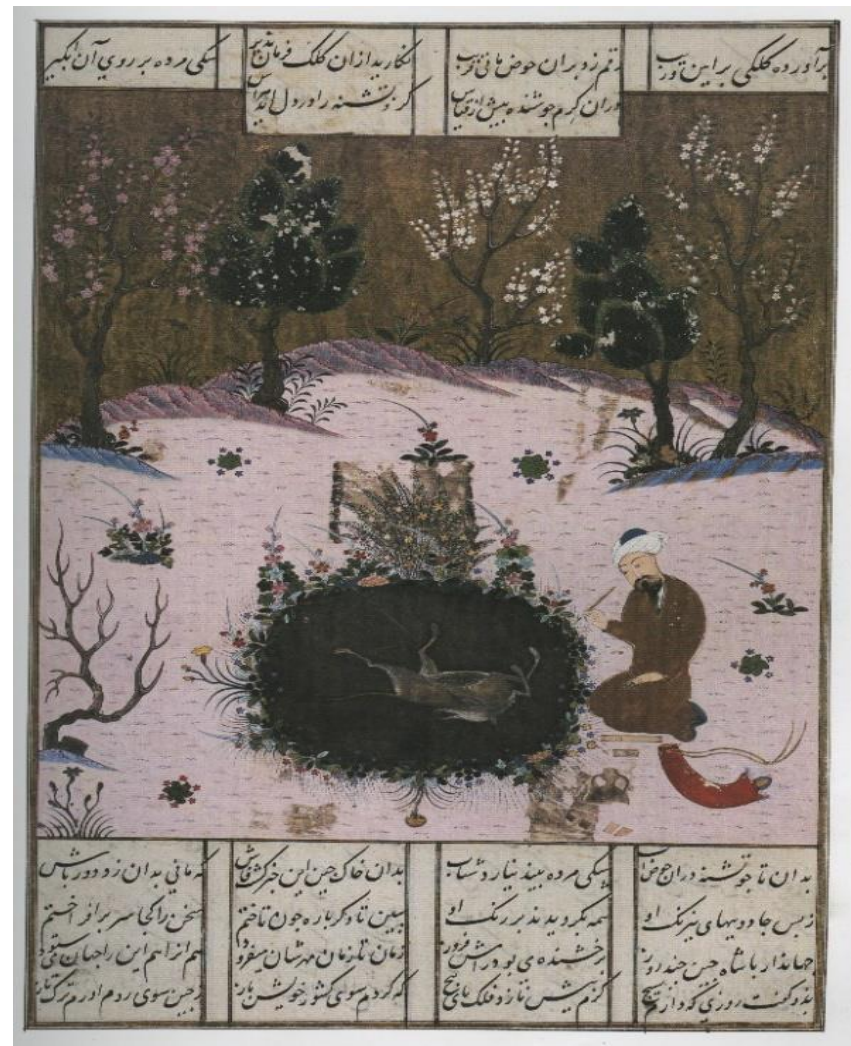

Pl.1: Mani paints a dead dog upon the magic chinese pool. Khamseh manuscript, copied in Yazd 1445 , (Barry, 2004, p. 265)

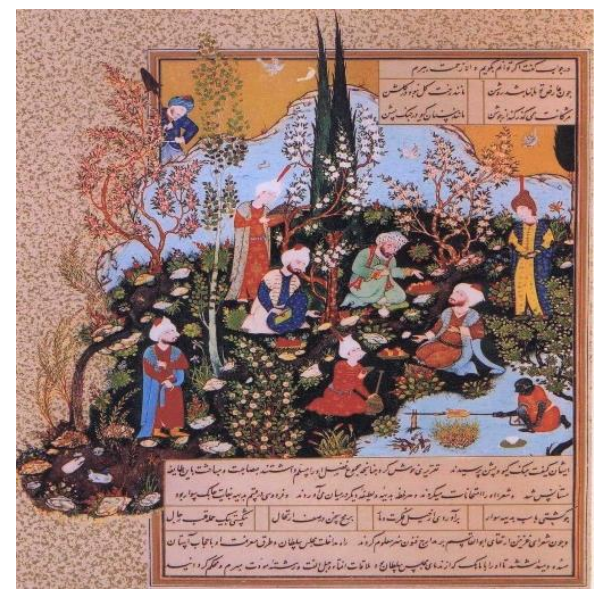

(i)

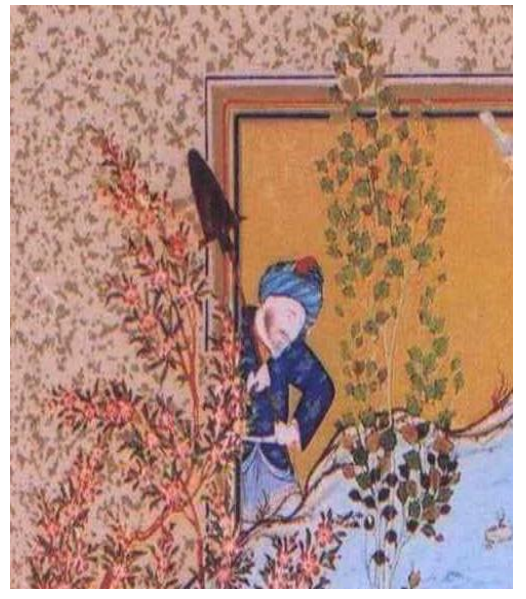

(ii)

Pl.2(i,ii): Portrait of Shah Tahmasp as a supervisor; Firdausi with three poets from Ghazna, Shahname's Tahmasp manuscript, Tabriz (939AH- 1532AD), Aqamirk, Metropolitan museum.(Khalifa, 2007, pl.9.) 


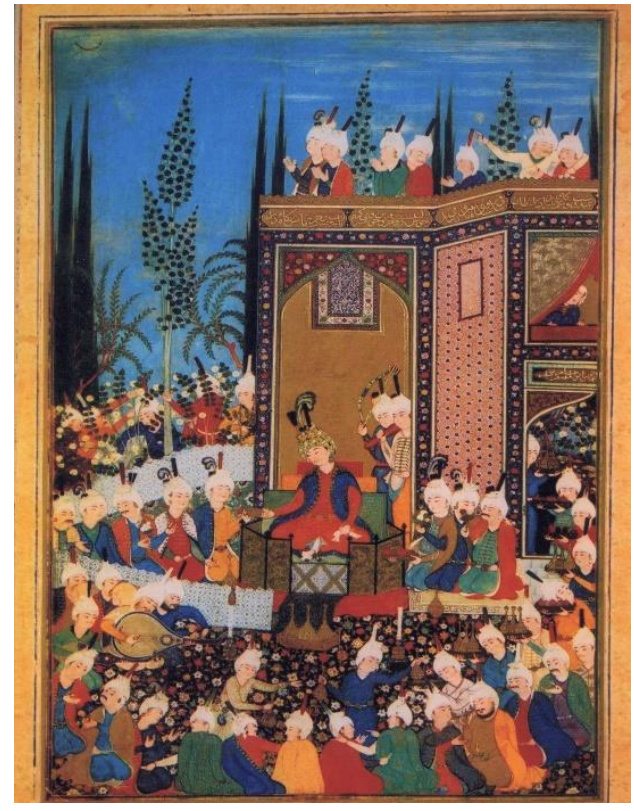

(i)

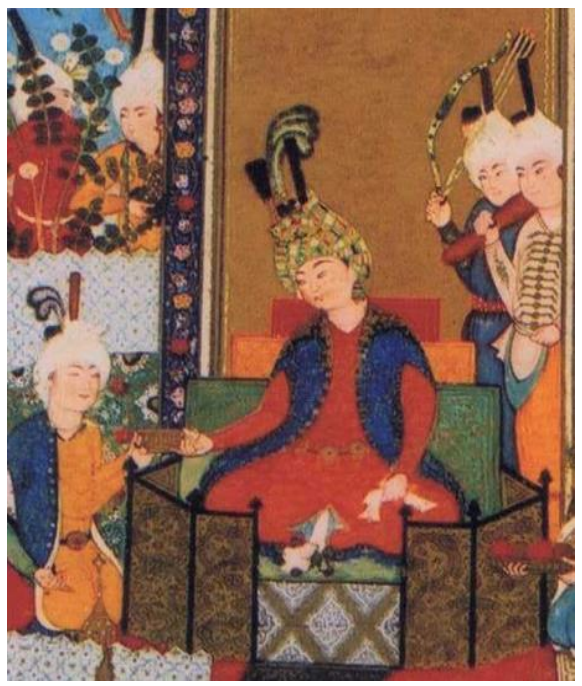

(ii)

Pl:3 (i, ii): Portrait of Sam Mirza as a patron ; The feast of I'd begins, copy of Diwan Hafiz manuscript(933-1527), Cartee privet collection, by Sultan Muhammed. (Welch, 1976, pl. 17)

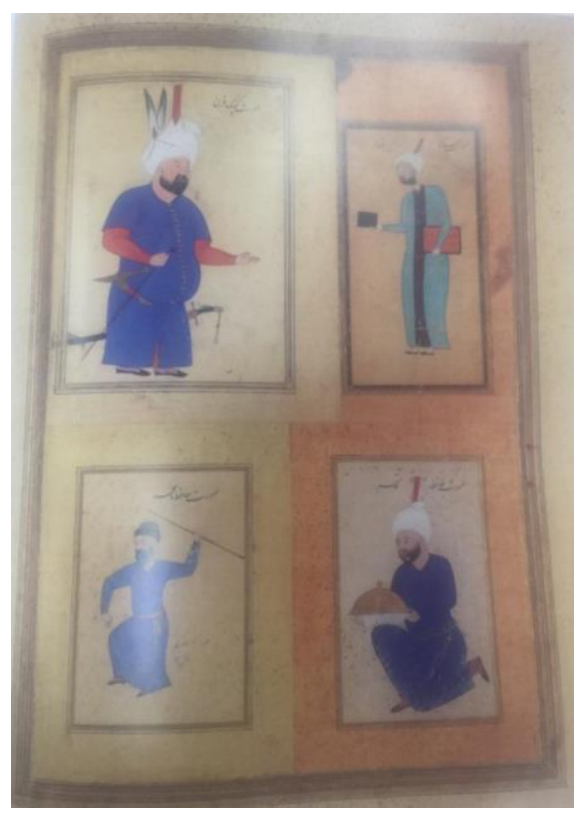

(i)

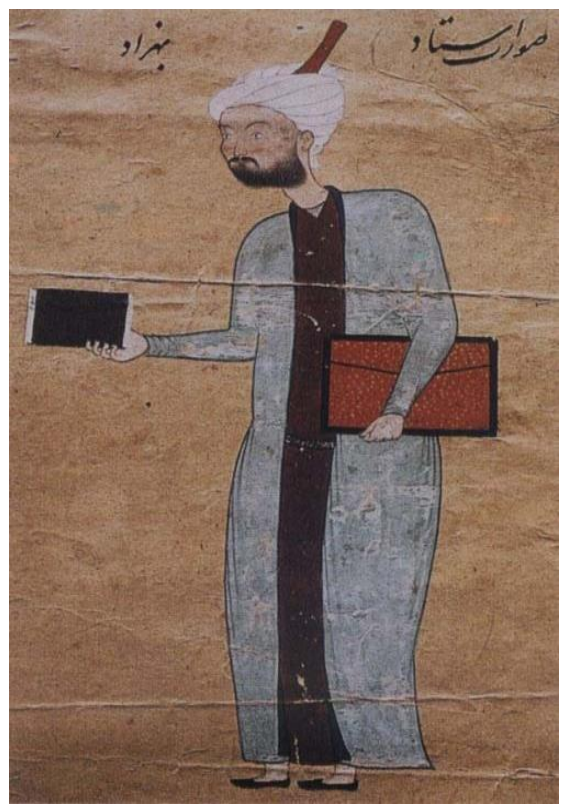

(ii)

Pl.4 (i, ii): Portrait of Bihzad (1511-1534), Shah Tahmasp's Album, (Rexburg, 2005, pl.108) 


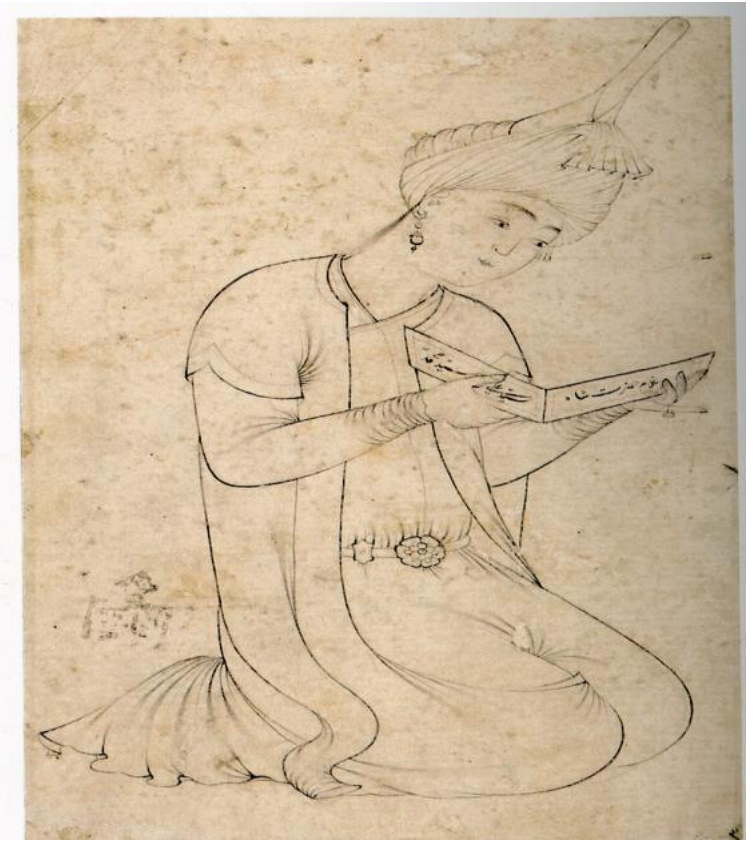

P1.5:Self-Portrait of Mir Sayed Ali (1540) Tabriz, the Freer Gallery, Smithsonian Institution. (Grabar, 2002, pl. 60.)

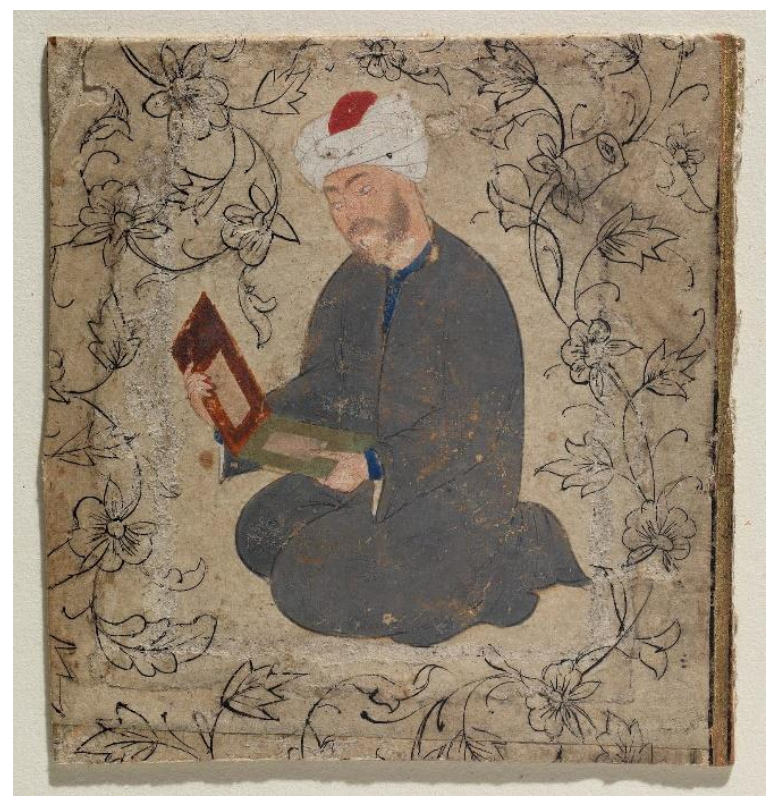

Pl.6: Portrait for a painter looks into an album Early $16^{\text {th }}$ century, Fine Art Museum, N.14.573, $4.8 \times 5.1 \mathrm{~cm}$ https://www.pinterest.com/pin/359162139033084057/

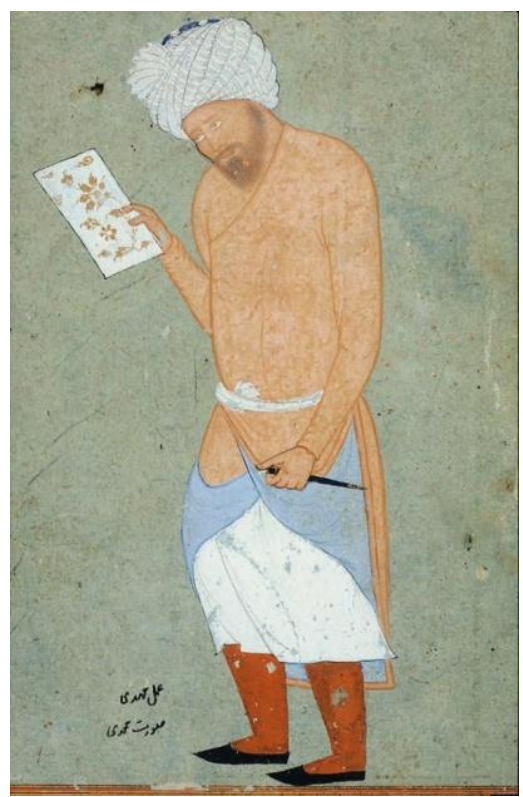

\section{Pl.7: Self-Portrait of Mohammedi} Museum of Fine Arts, Boston. Adamova, 2000, p.27, pl.4. 

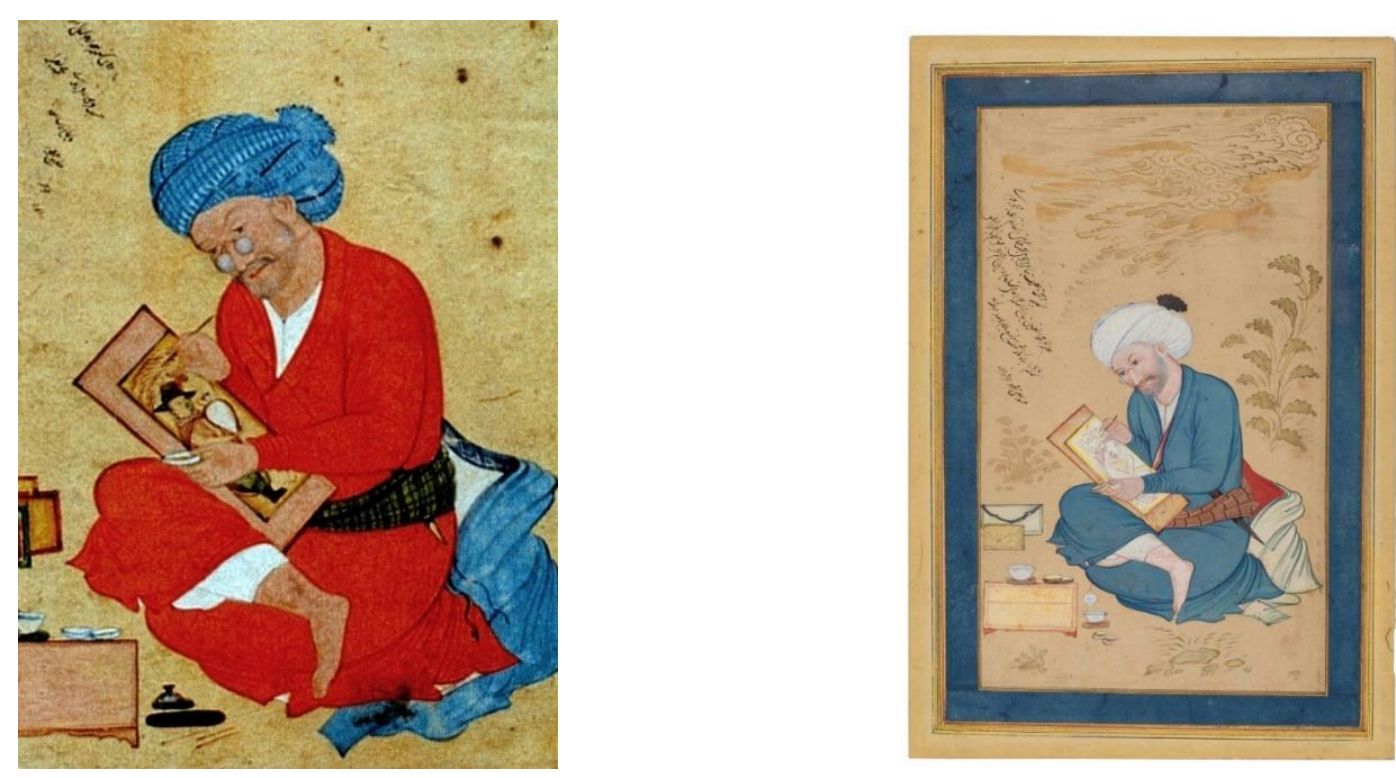

Pl.9: Portrait of Reza-i Abbasi, Isfahan 1635-1673. Pl. 10: Portrait of Reza-i Abbasi, Isfahan, Princeton University Library. 1676.

Diba, 1999, p.107, pl.4.

https://commons.wikimedia.org/w/index.php?curid=7828267 (12/2/2019)

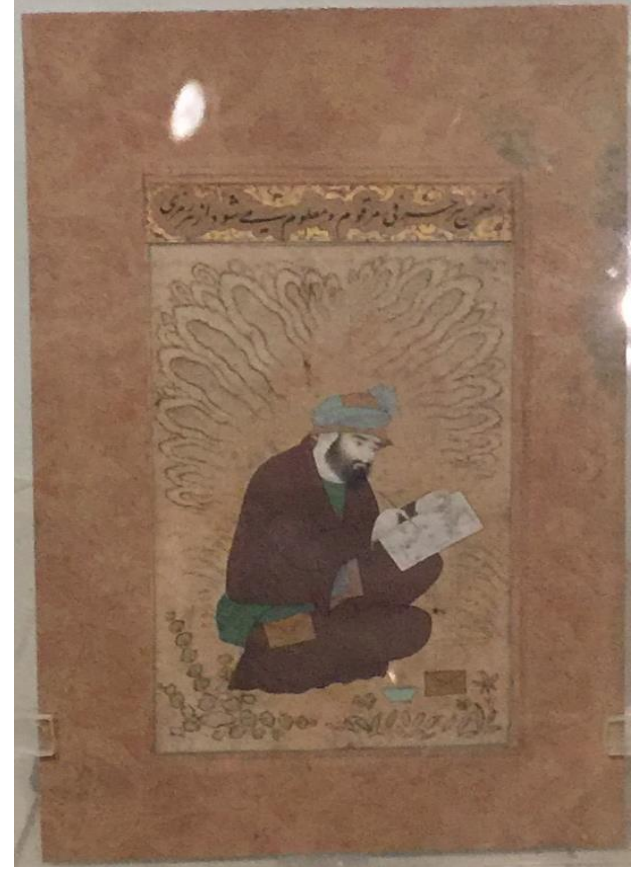

P1.8: Portrait of Safawi painter

Islamic art museum, Cairo.

With courtesy from Islamic art Museum in Cairo.

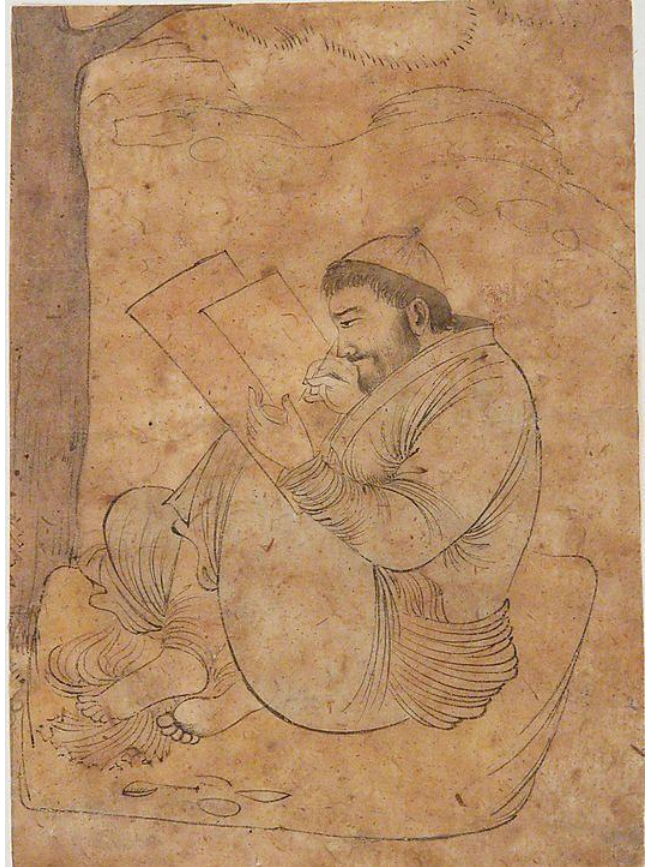

Pl. 11: Portrait of Safawi painter https://www.pinterest.com 


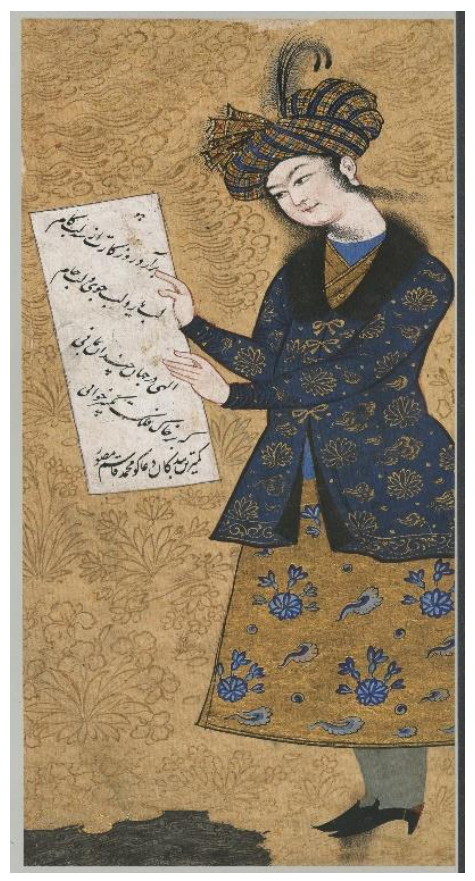

Pl.12:Self-portrait signed by Muhammad Qasim $17^{\text {th }}$ century, Sadr Uddin Aga Khan Collection,

Barry, 2004, fig.122 